\title{
Constraints/Challenges Faced In a Journey of Women Entrepreneurship in the Development in Western Maharashtra
}

\author{
Jadhawrao Madhavi Sugaraj $^{* 1}$, Dr. Salve P.S. ${ }^{2}$ \\ ${ }^{I}$ Research Scholar, Shri Jagdish Prasad Jhabarmal Tibrewala University, Vidyanagari, Jhunjhunu, Rajasthan \\ -333001 . \\ ${ }^{2}$ Department of Commerce, Shri Jagdish Prasad Jhabarmal Tibrewala University, Vidyanagari, Jhunjhunu, \\ Rajasthan - 333001 .
}

\begin{abstract}
The main objectives of the present paper are as follows: (i) To examine the factors responsible for growth of women entrepreneurship in India. (ii) To analyse the problems and challenges faced by the women entrepreneurs in India. (iii) To study the policy measures undertaken by the government and other agencies to promote women entrepreneurship in India. (iv) To examine the demographic profile of women entrepreneurs in small scale sector in Pune district, Maharashtra, India, (v) To analyze the various motivational factors responsible for women entrepreneurs to start up their own enterprise. (vi) To probe into challenges / constraints faced by women entrepreneurs to start up their own business. (vii) To suggest the framework for the promotion of women entrepreneurship in current scenario. In India, the need is now keenly felt that women should also work outside the home for getting better living standards for all. It is in this context that, the question of women entrepreneurs has taken new significance especially when unemployment has become a matter of great concern for all. Government of India has introduced the policy measures to promote the status and the level of female entrepreneurs in the country. There has been increasing turned in number of women owned enterprises in India, but despite government efforts, substantial growth could not be achieved. Very few entrepreneurs could approach the government assistance which is the indication that there is a need to revitalise the whole system. Keywords: Women Entrepreneurship, Government of India, Western Maharashtra, Constraints/Challenges.
\end{abstract}

\section{Introduction}

Women have proved themselves very successful entrepreneurs by engaging in one or two income generating ventures within the confines of their homes. The opportunity for developing the home-based small scale entrepreneurship has become more, due to increased level of education among women. The number of women, who acquire professional skills like engineering, managerial etc., has been increasing manifold today. However, a large proportion of such technically qualified women do not take up employment due to family pressures. There is an urgent need to promote avenues for these women to take up entrepreneurship in the twenty-first century in order to exploit their talents which otherwise go waste.

O'Meally-Nelson $(1991)^{1}$ in his study on "Small Business Opportunities for Women in Jamaica" revealed that women were concentrated in businesses which required the least capital outlay, or which were an extension of household activities, for example small scale retail or dress making/garment manufacturing. Carter and Cannon (1992) ${ }^{2}$ conducted a research to find the reasons for British women starting their own businesses, the problems they encounter, and the successful strategies they employed to overcome them. This is a case study of 60 successful female entrepreneurs and 10 women who closed down their businesses. Baijal and Asoken $(1997)^{3}$ in their study: "Banks and Women Enterprises Development: A Comparison of Approaches in India and UK",say that in India women enterprises are separately defined but in the UK women enterprises do not have any special and separate definition.

Nadkarni (1982) ${ }^{4}$ in her study: "Women Entrepreneurs: A Social and Economic Study with Reference to Pune", has presented her findings on problems and difficulties faced by women entrepreneurs in different industries. Rani (1986) $)^{5}$ in her study: "Potential Women Entrepreneurs", found that the desire to do something independently was the prime motivation factor to start a business activity amongst the sample respondents. For study purpose the respondents were selected during a Training Programme for Potential Women Entrepreneurs, held at Hyderabad in October 1985, organized by APITCO in collaboration with the Department of the Science, Technology and Environment, Government of Andhra Pradesh.

\section{Methodology}

In order to find out what constraint / challenges women entrepreneurs have faced in their journey as entrepreneur, total constraint were divided into 4 categories as constraint on personal level, social level, environmental level and general constraint they are still facing. 


\section{Personal Level Constraints}

In the category of personal level constraints 12 attributes were identified. The t- test performed to identify the significant personal level constraints faced by women entrepreneurs gives the output shown in Table 1.

Table 1: Personal Constraints

\begin{tabular}{|c|c|c|c|c|}
\hline \multirow[t]{2}{*}{ Personal Constraints } & \multicolumn{4}{|c|}{ Test Value $=3$} \\
\hline & $\mathbf{T}$ & df & Sig. (2-tailed) & Mean Difference \\
\hline $\begin{array}{l}\text { Lack of motivation and } \\
\text { confidence }\end{array}$ & 9.653 & 60 & 0.014 & -0.214 \\
\hline Role conflict & -1.028 & 40 & 0.500 & 1.745 \\
\hline Lack of leadership qualities & 21.503 & 44 & 0.056 & 0.076 \\
\hline $\begin{array}{l}\text { usceptibility about own } \\
\text { decision making abilities }\end{array}$ & 14.278 & 40 & 0.325 & -0.678 \\
\hline Orthodox family background & 10.245 & 61 & 0.030 & 0.359 \\
\hline Lack of finance & 23.733 & 56 & 0.040 & -1.589 \\
\hline Lack of security & 12.643 & 50 & 0.054 & 1.854 \\
\hline $\begin{array}{l}\text { Physical constraints like } \\
\text { pregnancy }\end{array}$ & 5.150 & 59 & 1.000 & -0.128 \\
\hline $\begin{array}{l}\text { Lack of support from } \\
\text { husband and family }\end{array}$ & 3.012 & 50 & 0.633 & 1.074 \\
\hline
\end{tabular}

The above table shows the factors which are personal level constraints for women entrepreneurs. The decision rule used to find out the significant factor is $\mathrm{t}$ value $>\mathrm{o}$ and sigma $<.05$ accordingly 6 factors i.e. lack of motivation and confidence, role conflicts, lack of leadership qualities, orthodox family background, lack of finance, maintaining work life balance proved to be significant factors. Hence, the remaining 6 factors namely poor self image, susceptibility about own decision making, lack of security, physical constraints like pregnancy, lack of support from husband and family, fear of failure and criticism were proved to be insignificant.

\subsection{Social Level Constraints}

In the category of social level constraints 4 attributes were identified ${ }^{6}$. The output of t- test performed to identify significant social level constraints is shown in Table 2.

Table 2: Social Constraints

\begin{tabular}{|c|c|c|c|c|}
\hline \multirow{2}{*}{ Social Constraints } & \multicolumn{3}{|c|}{ Test Value = 3 } \\
\cline { 2 - 5 } & $\mathbf{T}$ & $\mathbf{d f}$ & Sig. (2-tailed) & Mean Difference \\
\hline Discriminating treatment & 7.348 & 24 & 0.000 & 1.560 \\
\hline Lack of social acceptance & 3.653 & 47 & 0.014 & -1.214 \\
\hline Cultural values & -1.028 & 47 & 0.750 & 0.745 \\
\hline $\begin{array}{c}\text { socio-cultural problems } \\
\text { related to the basic ethics of } \\
\begin{array}{c}\text { the society, language, } \\
\text { religion etc }\end{array}\end{array}$ & -1.103 & 48 & 1.056 & 0.976 \\
\hline
\end{tabular}

The above table shows the factors which are social level constraints for women entrepreneurs. The decision rule used to find out the significant factor is $\mathrm{t}$ value $>0$ and sigma $<0.05$ accordingly only 1 factor i.e. Discriminating treatment was proved to be significant factor. Hence, the reaming 3 factors i.e. lack of social acceptance, Cultural values, socio-cultural problems related to the basic ethics of the society, language, religion etc.proved to be insignificant.

\section{Environmental Level Constraints}

In the category of Internal and external environmental level constraints 8 attributes were identified. The output of T Test performed to identify significant environmental level constraints is shown in Table 3, where shows the factors which are environmental level constraints for women entrepreneurs. The decision rule used to find out the significant factor is $t$ value $>o$ and sigma $<.05$. Accordingly 4 factors namely Understanding govt. rules and regulations, Lack of latest technology, Management of the workforce, Lack of managerial education were proved to be significant factor. 
Table 3: Environmental constraints

\begin{tabular}{|c|c|c|c|c|}
\hline \multirow{2}{*}{\begin{tabular}{c} 
Environmental constraints \\
\cline { 2 - 5 }
\end{tabular}} & \multicolumn{3}{|c|}{ Test Value = 3 } \\
\hline Local competition & 12.348 & 54 & 1.000 & Mean Difference \\
\hline $\begin{array}{c}\text { Understanding govt. rules and } \\
\text { regulations }\end{array}$ & 10.653 & 57 & 0.514 & -1.214 \\
\hline Marketing problems & -2.028 & 57 & 0.450 & 0.745 \\
\hline Lack of latest technology & -3.103 & 58 & 1.056 & 0.976 \\
\hline $\begin{array}{c}\text { Maintaining cordial } \\
\text { interpersonal relations }\end{array}$ & 17.936 & 64 & 0.643 & -0.634 \\
\hline $\begin{array}{c}\text { Understanding legal } \\
\text { compliance }\end{array}$ & 22.091 & 35 & 0.257 & -2.034 \\
\hline
\end{tabular}

The Hence, the reaming 4 factors i.e. Local competition, Marketing problems, Maintaining cordial interpersonal relations, Understanding legal compliance proved to be insignificant.

\section{Constraints Still Facing}

13 attributes were identified for the general constraints women entrepreneursBare still facing. The output of $\mathrm{T}$ Test performed to identify significant constraints still faced by respondents is shown in Table 4 .

Table 4: Constraints still facing

\begin{tabular}{|c|c|c|c|c|}
\hline \multirow[t]{2}{*}{ Constraints still facing } & \multicolumn{4}{|c|}{ Test Value $=3$} \\
\hline & $\mathbf{T}$ & df & Sig. (2-tailed) & Mean Difference \\
\hline Change in lifestyle & 10.348 & 50 & 0.000 & 1.600 \\
\hline Time Management & 7.653 & 51 & 0.314 & -1.014 \\
\hline Balancing work life & 5.028 & 50 & 0.050 & 0.045 \\
\hline Managing stress of decision making & 1.103 & 51 & 1.156 & 0.376 \\
\hline Competing in male dominated field & 12.036 & 24 & 0.643 & -0.434 \\
\hline Gender discrimination & 20.191 & 35 & 0.257 & -1.034 \\
\hline $\begin{array}{c}\text { Lack of awareness about legal } \\
\text { compliance }\end{array}$ & 2.046 & 43 & 0.216 & 0.463 \\
\hline $\begin{array}{l}\text { Lack of knowledge about technical } \\
\text { aspects }\end{array}$ & 11.987 & 65 & -0.213 & -1.203 \\
\hline Lack of training in my work area & 0.987 & 78 & -0.459 & -1.326 \\
\hline Lack of managerial excellence & 0.678 & 56 & 1.035 & -0.320 \\
\hline Reserve attitude of society & 0.456 & 49 & 1.032 & 1.275 \\
\hline Lack of government support & 0.345 & 58 & 0.345 & 1.320 \\
\hline $\begin{array}{l}\text { Lack of awareness about new trends } \\
\text { in business }\end{array}$ & 1.980 & 76 & 0.842 & 1.946 \\
\hline
\end{tabular}

The table below shows the constraints women entrepreneurs are still facing in their journey as entrepreneur. The decision rule used to find out the significant factor is $t$ value $>0$ and sigma $<.05$ accordingly 7 factors Balancing work life, Managing stress of decision making, Lack of knowledge about technical aspects, Lack of training in my work area, Lack of managerial excellence, Reserve attitude of society, Lack of government support were proved to be significant factor. Hence, the reaming 6 factors i.e. Change in lifestyle, Time Management, Competing in male dominated field, Gender discrimination, Lack of awareness about legal compliance, Lack of awareness about new trends in business proved to be insignificant ${ }^{7}$.

\section{Main features of women entrepreneurship in India}

\section{Results And Discussion}

\section{Growth of women entrepreneurship in India}

The number of business units owned and managed by females have increased manifold. As per the Annual Report the Ministry of Micro, Small and Medium Enterprise (MSME), Government of India, the total number of women enterprises has increased from 10.64 lakh to 20.21 lakh units i.e. almost doubled between 2001-02 and 2006-07. This is a very significant development. But India is still among the worst performing nations in women entrepreneurship according to the Global Entrepreneurship Survey, conducted by PC maker Dell and GEDI (Global Entrepreneurship and Development Institute) ${ }^{\mathbf{8}}$. Of the 17 countries surveyed India ranks 16th, just above Uganda. Status of higher education in women in India came out to be lower than most countries in the world (Economic Times, June7, 2013). Among the various states of India, those having more than 50,000 units of women enterprises include: the southern states of Kerala, Tamil Nadu, Karnataka and Andhra Pradesh, in the west, Maharashtra and Gujarat, in the north Uttar Pradesh and Punjab, in the east West Bengal and Odisha and in the central part Madhya Pradesh (Table 5). 


\begin{tabular}{|c|c|c|c|c|c|}
\hline $\begin{array}{l}\text { Units) and Percentage } \\
\text { Change (2001-02 to 2006- } \\
\text { 07) Selected States }\end{array}$ & $\begin{array}{c}\text { Third } \\
\text { Census }\end{array}$ & $\begin{array}{c}\text { Fourth } \\
\text { Census } \\
\text { Total }\end{array}$ & $\begin{array}{c}\text { Percentage } \\
\text { Change }\end{array}$ & $\begin{array}{c}\text { Fourth } \\
\text { Census } \\
\text { Registered }\end{array}$ & \begin{tabular}{c}
\multicolumn{2}{c}{ Fourth } \\
Census Un- \\
Registered
\end{tabular} \\
\hline All India & 10.64 & 20.21 & 89.94 & 2.15 & 18.06 \\
\hline Tamil Nadu & 1.30 & 3.57 & 174.62 & 0.54 & 3.03 \\
\hline Kerala & 1.39 & 2.69 & 93.53 & 0.38 & 2.31 \\
\hline West Bengal & 0.69 & 2.45 & 255.07 & 0.40 & 2.05 \\
\hline Karnataka & 1.03 & 2.12 & 105.82 & 0.26 & 1.86 \\
\hline Andhra Pradesh & 0.77 & 1.16 & 50.65 & 0.05 & 1.11 \\
\hline Madhya Pradesh & 0.68 & 1.16 & 70.59 & 0.10 & 1.06 \\
\hline Maharashtra & 1.00 & 1.03 & 3.00 & 0.18 & 0.85 \\
\hline Odisha & 0.38 & 0.92 & 142.11 & 0.02 & 0.90 \\
\hline Uttar Pradesh & 0.72 & 0.83 & 15.28 & 0.08 & 0.75 \\
\hline Punjab & 0.29 & 0.81 & 179.31 & 0.03 & 0.78 \\
\hline Gujarat & 0.53 & 0.80 & 50.94 & 0.23 & 0.57 \\
\hline
\end{tabular}

Source: Reports of the All India Census of MSME Units, Government of India.

\section{Distribution of Women Enterprises}

In terms of localization, majority of both the categories of women enterprises are established in the rural areas. Out of 18.06 lakh un-registered units, 12.79 lakh (70.82 percent) are in the rural areas and rest 5.27 lakh units (29.18 percent) are located in the urban areas. In case of 2.15 lakh registered units the rural-urban distribution is even i.e. 1.08 lakh units are established in the rural area and 1.07 lakh units are in the urban area (Table 6).

Table 6: Localization of Female Enterprises in India (lakh units) - (2006-07)

\begin{tabular}{|c|c|c|c|}
\hline Enterprise & Rural & Urban & All India \\
\hline Registered & $1.08(50.23)$ & $1.07(49.77)$ & $2.15(100.00)$ \\
\hline Un-Registered & $12.79(70.82)$ & $5.27(29.18)$ & $18.06(100.00)$ \\
\hline
\end{tabular}

Source: Report of the Fourth All India Census on MSME, 2006-07, Government of India.

*Figures in the parentheses indicate percentage.

From the view of type of enterprise operated, it was found that presence of women was maximum in the micro enterprise sector both in the registered and un-registeredsegments. As the data for 2006-07 shows, women control 14.19 percent of the registered micro units and 9.10 of the un-registered micro units at the all India level. Since the investment limit is very small and the risk factor is also being lower, most women have preferred to run micro units. In the small sector women have control over 5.06 percent of registered and 3.01 percent of the un-registered units. In the medium enterprise segment which involves higher investment of 1 to 5 crore, women participation is seen only in the registered sector and that too control over only 4.21 percent of the total units. With higher investment limit the risk factor in case of medium enterprises is also high. Only fewer well-to do women could afford to run such a project. More over they want guidance of government by registering the enterprise. Hence women participation here is low?

Table 7: Percentage of Type of Female Enterprises in India (2006-07)

\begin{tabular}{|c|c|c|}
\hline Type of Enterprise & Registered & Un-Registered \\
\hline Micro & 14.19 & 9.10 \\
\hline Small & 5.06 & 3.01 \\
\hline Medium & 4.21 & - \\
\hline Total & 13.72 & 9.09 \\
\hline
\end{tabular}

\section{Activity preference in women entrepreneurship}

From the 'activity' point of view most of the women enterprises are established as manufacturing units both in the registered and un-registered sectors. Out of 2.15 lakh registered units 1.08 lakh are manufacturing enterprises comprising 50.47 percent of the total and in the un-registered sector the figure is 13.13 lakh out of a total of 18.06 lakh units i.e 72.70 percent of the total. At the all India level women control 12.56 percent (87.44 for men) of the un-registered manufacturing units and 10.32 percent (89.68 for men) of the registered manufacturing units in rural and urban areas combined. 
Table 8: Activity preference in women entrepreneurship, 2006-07 (per cent)

\begin{tabular}{|c|c|c|c|c|c|}
\hline Enterprise & $\begin{array}{c}\text { Registered } \\
\text { Enterprises (\% } \\
\text { distribution of } \\
\text { Regd.Female } \\
\text { Enterprise) }\end{array}$ & $\begin{array}{c}\text { \% Distribution of } \\
\text { Regd. Female } \\
\text { Enterprise To } \\
\text { Total Regd. Ent. } \\
\text { In India (Male \& } \\
\text { female) }\end{array}$ & $\begin{array}{c}\text { Unregistered } \\
\text { enterprises (\% } \\
\text { Distribution of } \\
\text { Unregd. Female } \\
\text { Enterprise) }\end{array}$ & $\begin{array}{c}\text { Un-regd. Female } \\
\text { Ent. As percentage } \\
\text { of total Unregd. Ent. } \\
\text { In India (Male and } \\
\text { Female) }\end{array}$ & $\begin{array}{c}\text { All IndiaTotal } \\
\text { Female Ent. } \\
\text { Regd.+Un- } \\
\text { regd. }\end{array}$ \\
\hline $\begin{array}{c}\text { ACTIVITY } \\
\text { WISE }\end{array}$ & & & 72.70 & 12.56 & 7.31 \\
\hline Manufacturing & 50.47 & 10.32 & 4.98 & \\
\hline $\begin{array}{c}\text { Repair \& } \\
\text { Maintenance }\end{array}$ & 8.55 & 7.00 & 22.31 & & 7.23 \\
\hline Services & 40.98 & 34.85 & & 5.92 \\
\hline
\end{tabular}

Source: Report of the Fourth All India Census on MSME, 2006-07, Government of India. (Percentages are calculated from the data)

The second preferential activity seems to be the 'services units' which account 40.98 percent the total registered units (about 88 thousand out of 2.15 lakh) and 22.31 percent of the total un-registered units (4.03 lakh out of 18.06 lakh) at the all India level. At the all India level women control 34.85 percent the total registered services enterprises as against 65.15 percent for males while in the same for un-registered services enterprises stood at 4.92 for women as against 95.08 for males in both rural and urban area combined. The last in the preference pattern for women comes out to be "repairing and maintenance" in which 8.55 percent being in the registered sector and 4.98 percent in the un-registered sector ${ }^{\mathbf{1 0}}$. At the all India level i.e combining registered and unregistered units in rural and urban areas, it was calculated that women enterprises constitute 12.36 percent of the total manufacturing units, 7.23 per cent of the total Repair and Maintenance units and 5.81 per cent of the total services units (Table 8).

\section{Operational feature of women entrepreneurship}

In Table 9 it is shown that 97.12 percent registered enterprises and 92.58 percent of the un-registered enterprises are operated throughout the year or 'perennial 'in nature which is quite remarkable. Less than 3 percent of both the type of enterprises are 'seasonal' in nature. About 4.15 percent un-registered enterprises and a very negligible amount of 0.40 percent registered enterprises are found out to be 'casually' run ${ }^{11}$. At the all India level i.e combining registered and un-registered units in rural and urban areas, it was calculated that women enterprises constitute 9.34 percent of the total perennially working units, 7.70 per cent of the total seasonal units and 17.84 per cent of the total casually working units (Table 9).

Table 9: Operational feature of women entrepreneurship, 2006-07

\begin{tabular}{|c|c|c|c|c|c|}
\hline Enterprise & $\begin{array}{l}\text { Registered } \\
\text { (Female } \\
\text { Enterprise) }\end{array}$ & $\begin{array}{l}\text { Percentage of } \\
\text { Female } \\
\text { Enterprise to } \\
\text { total Regd. } \\
\text { Enterprise } \\
\text { (Male \& } \\
\text { Female) }\end{array}$ & $\begin{array}{c}\text { Un } \\
\text { Registered } \\
\text { Female } \\
\text { Enterprise }\end{array}$ & $\begin{array}{l}\text { Percentage of } \\
\text { Female } \\
\text { Enterprise to } \\
\text { Total Unregd. } \\
\text { Enterprise } \\
\text { (Male \& } \\
\text { Female) }\end{array}$ & $\begin{array}{l}\text { All India Total } \\
\text { Regd.+Un- } \\
\text { regd. }\end{array}$ \\
\hline \multicolumn{6}{|l|}{$\begin{array}{l}\text { OPERATION } \\
\text { WISE }\end{array}$} \\
\hline Seasonal & 2.48 & 11.49 & 2.66 & 7.48 & 7.70 \\
\hline Casual & 0.40 & 24.78 & 4.15 & 17.73 & 17.84 \\
\hline
\end{tabular}

Source: Report of the Fourth All India Census on MSME, 2006-07, Government of India. (Percentages are calculated from the data)

\section{Organizational set up of women entrepreneurship}

In terms of organizational set up (Table.6) women prefer to have sole proprietary units. In fact 86.05 percent of the registered enterprises and 93.47 percent un-registered enterprises are sole proprietary units. Other form of organizations such as partnership, private company, public limited company or cooperatives is very negligible among women enterprises. At the all India level i.e. combining registered and un-registered units in rural and urban areas, it was calculated that women enterprises constitute only 1.00 percent of the total Proprietary units, 10.81 per cent of the total Partnership units, 4.08 per cent of the total Private Company units, and 14.28 per cent the total Cooperative units and 14.53 per cent of the total other units ${ }^{12}$. Women Participation in forming Public Limited Companies is very very negligible (Table 10). 
Table 10: Organizational set up of women entrepreneurship 2006-07

\begin{tabular}{|c|c|c|c|c|c|}
\hline Enterprise & $\begin{array}{c}\text { Percentage } \\
\text { of } \\
\text { Registered } \\
\text { (Female } \\
\text { Enterprise) }\end{array}$ & $\begin{array}{l}\text { Percentage of } \\
\text { Female } \\
\text { Enterprise } \\
\text { in Regd. Sec. } \\
\text { to total (Male } \\
\text { \& Female) }\end{array}$ & $\begin{array}{c}\text { Percentage of } \\
\text { Un } \\
\text { Registered } \\
\text { (Female } \\
\text { Enterprises) }\end{array}$ & $\begin{array}{l}\text { Percentage of } \\
\text { Female } \\
\text { Enterprise } \\
\text { in Unregd. } \\
\text { Sec. to total } \\
\text { (Male \& } \\
\text { Female) }\end{array}$ & $\begin{array}{l}\text { All India } \\
\text { Total } \\
\text { + Un-regd. } \\
\text { Und. }\end{array}$ \\
\hline \multicolumn{6}{|l|}{$\begin{array}{c}\text { ORGANISATION } \\
\text { WISE } \\
\end{array}$} \\
\hline Proprietary & 86.05 & 13.11 & 93.47 & 9.02 & 1.00 \\
\hline Partnership & 2.62 & 8.96 & 1.66 & 11.32 & 10.81 \\
\hline Pvt. Company & 1.56 & 5.71 & 0.00 & 0.00 & 4.08 \\
\hline Pub.Ltd.Company & 0.37 & 9.42 & - & - & - \\
\hline Cooperative & 0.51 & 23.09 & 0.17 & 13.04 & 14.28 \\
\hline Others & 9.30 & $\mathbf{5 5 . 5 3}$ & 1.27 & 8.91 & 14.53 \\
\hline Total & 100.00 & - & 100.00 & - & - \\
\hline
\end{tabular}

\section{Performance of the women enterprises}

Table 11 summarizes the performance of the women enterprises in terms of certain characteristics such as employment generation, gross output, market value of fixed assets and exports.

Table 11: Performance of the Women Enterprises (Percentage to Total)

\begin{tabular}{|c|c|c|}
\hline Variables & Third Census (2001-02) & Fourth Census (2006-07) \\
\hline Employment Generation & 7.14 & 7.00 \\
\hline Gross Output & 3.46 & 6.21 \\
\hline Market Value Of Fixed Asset & 4.63 & - \\
\hline Export & 2.37 & \\
\hline
\end{tabular}

Report of the Fourth All India Census on MSME, 2006-07, Government of India.

As the Table 11 shows, there has been improvement in the performance of the women led enterprises over time. Because of increase in gross output by more than 3 percent, employment generation increased by one percent between 2001-02 and 2006-07. The market values of fixed assets have also increased by around 2 percent. In 2001-02 the contribution to export was 2.37 percent which marks the presence of women entrepreneurs on the global platform.

\section{Summary And Conclusion}

Women entrepreneurs encounter many problems in their efforts to develop the enterprises they have established. The main problems faced by the women entrepreneurs may be analysed as follows ${ }^{13}$.

Shortage of Finance: Women and small entrepreneurs always suffer from inadequate financial resources and working capital. They are lacking access to external funds due to absence of tangible security and credit in the market. Since women do not generally have property in their names they lack security to avail loan. Also the complicated procedure of bank loans, the inordinate delay in obtaining the loans and the running about along with the transaction cost involved there in work as deterrents against many women who aspire to be entrepreneurs.

Inefficient arrangements for Marketing and Sales: For marketing their products, women entrepreneurs are often at the mercy of the middlemen who pocket the chunk of profit. Further, women entrepreneurs find it difficult to capture the market and make their products popular. This problem is all the more serious in the case of food production and processing ventures.

Stiff Competition: Many of the women enterprises have imperfect organizational setup. They have to face severe competition from organized industries and male entrepreneurs. For example, women cooperatives engaged in hand pounding of rice in Kerala confronted heavy competition from mechanised rice mills which resulted in the liquidation of many units in the traditional sector.

Lack of Education: In India literacy among women is very low. Due to lack of education, majority of women are unaware of technological developments, marketing knowledge, etc. Lack of information and experience creates further problems in the setting up and running of business enterprises. 
Low Ability to Bear Risk: Women have comparatively a low ability to bear economic and other risks because they have led a protected life. Sometimes, they face discrimination in the selection for entrepreneurial development training. Some of them lack entrepreneurial initiative or specialised training. Inferiority complex, unplanned growth, lack of infrastructure, late starts etc. is other problems of women entrepreneurs in India.

Social Attitude: The biggest problem of a women entrepreneur is the social attitude and the constraints in which she has to live and work. Despite constitutional provisions, there is discrimination against women. In a tradition bound society, women do not get pro-active support from family members. Their hopes and aspirations are never cared for in the name of "family prestige "and "discipline". Preference to boys and discrimination against girls are well known practices amongst majority Indian families.

Low Mobility: One of the biggest handicaps for women entrepreneurs is mobility or travelling from place to place. Women on their own find it difficult to get accommodation in smaller towns. A single woman asking for accommodation is still looked upon with suspicion.

Family Responsibilities: In India, it is mainly a woman's duty to look after the children and other members of the family. Her involvement in family leaves little energy and time for business. Married women entrepreneurs have to make a fine balance between business and home. Without the support and approval of husband, the female entrepreneurs cannot succeed. Despite modernisation, tradition and family responsibilities slow down the movement of women.

\section{Government policy for development of women entrepreneurship}

The government of India and the various state governments have come up with policies and programmes to assist women entrepreneurs and help in solving the above stated challenges and problems which they face. A brief account of these policies and programmes are given below.

Policy Initiatives: Government of India is committed to develop MSMEs in general and women entrepreneurship in particular. In a broad manner the government has implemented the MSME Development Act 2006 which has already come into effect. There is a provision to reserve items exclusively for the MSMEs. At present 20 items are reserved for these sectors. However depending on the factors such as economies of scale, level of employment, prevention of concentration of economic power etc. there are possibilities of dereservation also. The govt. has also launched National Manufacturing Competitiveness Programme (NMCP) to encourage competitiveness in this sector. Women entrepreneurship has been benefiting from these policy initiatives $^{14}$.

\section{Conclusion}

There has been a steady increase in the participation of women in small business indicating immense potential for entrepreneurial development among them. From the point of view of performance, it was observed that the women enterprises in India have made significant contribution towards generation of employment, gross output, asset creation and exports. Women form the family, which participate to develop society and Nation. Entrepreneurial movement among women started late and is still in its infancy. Changes in the global and domestic environment have contributed towards the growth of women entrepreneurship in India. As observed the success of women entrepreneurs differs from State to State in India. It was also observed that women enterprises are concentrated in the micro segment of the MSME sector. To enlarge their participation in small and medium segments a stronger coordinated role of Indian Government, financial institutions, voluntary agencies and educational institutions with an integrated approach is necessary. Young female entrepreneurs should share their success stories in the world of e-commerce to speed up entrepreneurial movement in India. Women entrepreneurs will be better understood and encouraged by studying and focussing (i) their social and cultural background including family system (ii) religion and caste and (iii) location where they are staying, e.g., whether it is urban area or rural area or district or block.

\section{References}

[1]. Blossom, O'Meally-Nelson, "Small Business Opportunities for Women in Jamaica : A Comment",SEDME, Vol. XVIII, National Institute of Micro, Small and Medium Enterprises, March 1991.

[2]. Carter, Sara and Cannon, Tom, Women as Entrepreneurs: A Study of Female Business Owner, Their Motivations, Experiences and Strategies for Success, London and New York Academic Press, 1992.

[3]. Choudhury, P. K. Shashi, Baijal and Asokan, M. (1997), "Bank and Women Enterprise Development: A Comparison of Approaches in India and UK", SEDME, XXIV, National Institute of Micro, Small and Medium Enterprises, June 1997.

[4]. Nadkarni, Sulochana, "Social and Economic Study of Women Entrepreneurs with Reference to Pune", Ph.D. Thesis Pune University, 1982. 
[5]. Rani, "Potential Women Entrepreneurs", A study, SEDME 13(3), National Institute of Micro, Small and Medium Enterprises, 1986, pp.13-32.

[6]. Gundry T.T., L.K., \& Welsch, H.P., Women entrepreneurship in Asian developing countries: Their development and main constraints, Journal of Business Venturing, 2001, Vol.16, No-5, pp. 453-470.

[7]. Kulkarni M., Entrepreneurship Development and Project Management, Nirali prakashan, New Delhi. Mizgajska H., Education as Determinant of Motivation and Performance of Women -Owned Small Firms. Evidence from Poland, 2009.

[8]. Goplan, S: "Employment of Women: The Indian Situation", Second International Conference of Women Entrepreneurs, NAYE, New Delhi, 1981.

[9]. Kollan,Bharti and Indira J Parikh “A Reflection of the Indian Women in Entrepreneurial World”, IIM Ahmedabad : Research and Publications, W.P. No. 2005-08-07, August 2005

[10]. Lesa Mitchell Ewing Marion Kauffman Foundation,Sept. "Overcoming the Gender Gap: Women Entrepreneurs as economic drivers", 2011

[11]. Mishra D.N. "Entrepreneur and Entrepreneurship Development and Planning in India", Oscar Publications, New Delhi, 1990.

[12]. Goyal, Meenu and Jai Parkash "Women Entrepreneurship in India-Problems and Prospects", International Journal of Multidisciplinary Research, September 2011, Vol.1 Issue 5, ISSN 22315780.

[13]. Neff, Damieu, Kunal Sen and Veronika kliny - "The Puzzling decline in Rural women's Labour force participation in India: A reexamination", G/GA Research Unit: Institute of Asian Studies, working paper, May 2012, No. 19.

[14]. Shankar,P., "WOMAN ENTREPRENEUR IN INDIA -OPPORTUNITIES AND CHALLENGES", International Monthly Refereed Journal of Research In Management \& Technology, January 2013, Volume II. 